\title{
LOS CRUCEROS DE SAN ANDRÉS DE TEIXIDO Y SUS CAMINOS DE PEREGRINACIÓN
}

\author{
Por \\ JUAN J. BURGOA FERNÁNDEZ
}

\section{RESUMEN}

El camino de peregrinación a San Andrés de Teixido constituye una de las rutas más ancestrales y conocidas de la Comunidad de Galicia. Como la mayoría de los viejos caminos gallegos, esta ruta todavía está jalonada de tradicionales cruceros que, a su función utilitaria de indicadores del camino y lugar de descanso del peregrino, unen sus características religiosas y etnográficas que dotan a los viajes de un sentido sacro y los envuelven en una atmósfera mágica.

\section{PALABRAS CLAVE}

Crucero, camino, encrucijada, peregrinación, romería, arte popular, Patrimonio Cultural, etnografía.

\begin{abstract}
The way of pilgrimage to San Andrés of Teixido constitute one of the more ancients and known routes of the Community of Galicia. As the majority of the old ways galicians, this route is yet marked by traditionals
\end{abstract}

«CUADERNOS DE ESTUDIOS GALLEGOS», Tomo L, Fascículo 116, Santiago 2003. 
high-crosses that, to your function of utility of indicators of the way and place of rest of the pilgrim, join yours characteristics religious and etnográphicals, that endowed to the journeys of an holly sense and involved them in a magic atmosphere.

\section{KEYWORDS}

High-cross, way, cross-road, pilgrimage, popular art, Cultural Patrimony, etnography.

\section{EL SANTUARIO DE SAN ANDRÉS DE TEIXIDO}

En los agrestes acantilados de la costa atlántica que rodean por el Norte al municipio de Cedeira, dentro de una amplia hondonada a 140 metros sobre el nivel del mar, se encuentra el Santuario de San Andrés de Teixido, perteneciente a la parroquia de Santa María de Régoa. Está rodeado por la sierra de A Capelada, espacio natural de impresionantes panorámicas y suelos de notable interés geológico con presencia de minerales como serpentinita y dunita, variada vegetación con endemismos florales y abundante fauna, destacando además la presencia de caballos cimarrones y de ganado vacuno en libertad.

Aunque la presencia humana en el lugar está atestiguada desde la Edad de Bronce, hay constancia documental de que en el siglo XII se levantaba allí un antiguo monasterio relacionado con la orden de San Juan de Jerusalén o de los Caballeros de Malta, aunque posiblemente hubiese presencia eremítica desde siglos atrás. La devoción de este lugar se fue transmitiendo de generación en generación posibilitando que tan interesante romería de origen remoto llegase hasta nuestros días.

La actual iglesia de San Andrés es un pequeño templo de épocas posteriores, sin valor artístico especial. De todas formas conserva interesantes elementos arquitectónicos del siglo XVI tales como una bonita puerta de arco conopial y los restos de unas pinturas al fresco en el testero, mientras su interior aparece lleno de velas y variados exvotos, un policromado retablo barroco con expresivas imágenes de sabor popular y una curiosa imagen-relicario de San Andrés de estilo manierista. 
El interés del santuario radica también en la historia de sus antiguas romerías y peregrinaciones, donde se mezclan, como residuo de viejos cultos anteriores al Cristianismo, una serie de leyendas y devociones populares, tradiciones paganas, ritos etnográficos, romances y cantigas populares y relatos milenarios, todo ello enmarcado en un llamativo entorno de sugestivas características naturales.

\section{LA LEYENDA DEL APÓSTOL SAN ANDRÉS}

De la misma manera que, según diferentes leyendas, llegó a Galicia por mar el cadáver del Apóstol Santiago a Padrón y la Virgen María lo hizo a Muxía, San Andrés, pescador antes que apóstol, llega al lugar de Teixido en una barca que, según la tradición, luego vuelca y se petrifica. En recuerdo de este hecho, el mayor de los rocosos islotes de las cercanas islas Gabeiras lleva el nombre de la Barca del Santo.

Más tarde, cuando Cristo en unión de San Pedro llega andando a Teixido, como la comida escaseaba, le piden ayuda a Dios que les mandó una manzana en la que se encontraba escondido San Andrés. Al partir la fruta por la mitad San Andrés quedó libre y el Salvador pensó que el Señor se lo había mandado para que se quedase en Teixido.

$\mathrm{Al}$ ver un lugar tan solitario e inhóspito, San Andrés se queja amargamente de las pocas visitas que va a recibir en un santuario situado en aquel lugar tan lejano, motivo de que también fuese conocido como San Andrés de Lonxe, en comparación con el abundante número de peregrinos que iban a Compostela.

Compadecido, el Señor le promete una romería tan nombrada que sólo desaparecerá cuando el mundo se acabe, de tal manera que aquel que no haga el camino a Teixido de vivo, lo hará luego de muerto. De ahí el ancestral respeto a los reptiles (serpientes y lagartos) que los peregrinos encuentran en su camino por tratarse de las ánimas de aquellos que no cumplieron en vida con el rito del peregrinaje.

Otra forma de ir a San Andrés después de muerto es hacerlo en espíritu, por medio de algún familiar que recoge el ánima de su tumba del cementerio y la acompaña en el camino a Teixido, incluso llevándole la comida que luego se entrega a alguno de los pobres de los que se encuentran en el camino. 
De esta manera se va forjando a lo largo del tiempo una creciente peregrinación popular de la que ya hay noticias escritas el siglo XIV y que ya los siglos XVII y XVIII llega a registrar una mayor afluencia que la de Santiago de Compostela, constituyendo no sólo un recuerdo perenne en la memoria histórica de los habitantes de las comarcas de Ferrol y Ortegal sino también una cita inexcusable para el país gallego y una referencia obligada como santuario de amor y muerte dentro de la singular etnografía de esta Comunidad.

A las leyendas sobre San Andrés hay que añadir las innumerables y variadas coplas y cantigas referentes a su afamada romería, las canciones y foliadas así como algunos romances antiguos, de los que el más conocido es el de la Dama Gelda.

\section{LAS PEREGRINACIONES A SAN ANDRÉS Y SUS RITOS TRA- DICIONALES}

Pese a la nueva carretera que hoy prácticamente llega al lugar donde se levanta la iglesia, durante todo el año se registra una regular asistencia de peregrinos que se siguen trasladando a pie al santuario de San Andrés, en especial durante la temporada estival. Aunque el día de San Andrés se celebra el 30 de Noviembre, el período de las romerías «grandes», como son conocidas las de mayor afluencia, es el comprendido entre el 16 de Agosto y el 9 de Septiembre.

La mayoría de los caminos a Teixido confluyen en el lugar de Porto de Cabo, lugar donde los romeros descansaban y reponían sus fuerzas con los tazones de caldo que les vendían a módico precio las caldupeiras, mujeres que lo preparaban al borde de la ruta.

En la romería se manifiesta una serie de ritos y prácticas de carácter supersticioso y pagano, entreverados con cultos de la liturgia cristiana. Tal es el caso de la ancestral costumbre de formar a lo largo del camino una serie de amilladoiros, montones de pequeñas piedras depositadas en su viaje por los peregrinos con el objeto de desprenderse de sus pecados o como testimonio de sufragios por las ánimas del purgatorio. Muchos de estos amilladoiros se encuentran hoy cubiertos por la vegetación especialmente en el lugar de Viriño, antes de llegar al Cristo de los Carrís.

Los peregrinos que acuden a San Andrés lo hacen a pie desde diferen- 
tes lugares, portando sus ofrendas, largas velas o diversos exvotos que luego depositarán en el santuario lo mismo que la acostumbrada limosna. Hoy en día ya no portan los largos hábitos con que se vestían en tiempos pasados, tampoco suelen hacer de rodillas ya las empinadas bajadas penitenciales y han dejado de verse los ataudes con que algunos de ellos se presentaban y que luego dejaban en la capilla.

El peregrino no suele abandonar el santuario sin previamente asistir a alguna misa, en especial la mayor o «misote» y luego cumplir con el rito conocido con el nombre de poner el santo, es decir que le den a besar y le persignen con una pequeña imagen de San Andrés, mientras recita los apropiados ensalmos o fórmulas verbales.

Después de la visita a la capilla hay que bajar a la Fuente del Santo para empapar los pañuelos que aplican a sus partes enfermas o para beber de los tres caños de agua como paso previo a la petición de favores y las prácticas adivinatorias por medio de la miga de pan en la pileta de la fuente. Luego hay que descender todavía más, casi hasta la orilla del mar, para que algunos puedan recoger la hierba de enamorar o clavel marino y otras hacerse con los afamados juncos de buen parir.

Después de la procesión, la posterior comida campestre, en la que no debe faltar la empanada, y los bailes al son de la gaita, llega el momento de la vuelta. Para ello, ademas de adquirir las clásicas medallas y estampas, hay que cumplir otra de las tradiciones de la romería, la composición del tradicional ramo elaborado con una vara de avellano y unas ramitas de tejo (de cuyo nombre gallego de Teixo se hace derivar el topónimo del lugar).

Por último, el romero debe adornar su ramo con las típicas figuras de miga de pan sin fermentar, endurecidas al horno y pintadas de vivos colores, conocidas como «sanandreses» y que sustituyen a las antiguas figuras de cobre y latón que hoy ya no se encuentran.

\section{LOS CAMINOS DE LOS ROMEROS}

Tal como ocurre con las diversas rutas históricas de peregrinación a Santiago de Compostela y con los diferentes itinerarios que conducen a los romeros a los abundantes santuarios gallegos, son varios los caminos que a lo largo del tiempo se fueron estructurando y que fueron siguiendo los peregrinos que se dirigían al santuario de San Andrés.

«CUADERNOS DE ESTUDIOS GALLEGOS», Tomo L, Fascículo 116, Santiago 2003. 
Uno de estos históricos caminos a Teixido es el conocido como Camiño Vello que lleva al santuario de San Andrés desde el monasterio de San Martiño de Xuvia en O Couto, tratándose realmente de un camino con diversas variantes dentro de una densa red viaria de comunicación entre aldeas, siendo también utilizada como ruta comercial por ganaderos y madereros.

Este itinerario al santuario de San Andrés fue el que siguió el padre Martín Sarmiento en su conocido viaje a Galicia los años 1754 y 1755 , desde su alojamiento en el monasterio de San Martiño do Couto en Xubia. De los lugares recorridos en el camino de ida y la ligera variante que utilizó para su regreso dejó una relación escrita con interesantes comentarios de orden toponímico, biológico y etnográfico.

De una manera resumida los hitos y lugares más interesantes del Camiño Vello son el monasterio de San Martiño do Couto, el molino das Aceñas, el castro de Sequeiro, el lugar de Pena de Embade con la piedra oscilante, el monte dos Nenos, el marco de Portonovo, la iglesia de San Pedro de Loira, la capilla da Fame en Liñeiro, la aldea de Porto do Cabo, el río das Mestas, el casal dos Freires, las fuentes das Virtudes y do Altar en Candales, la ermita de San Roque de Reboredo, el Cristo dos Carrís, las bajadas da Costa Grande y da Costa Pequena y, por último, el Santuario de San Andrés de Teixido, una parte importante de estos sitios sacralizados por el correspondiente crucero.

En diversos lugares de este Camiño Vello confluyen otros caminos como es el caso del que seguían los romeros procedentes de la comarca de Ferrol donde visitaban las ermitas de San Cristóbal en A Graña y de Santa Comba en Cobas y el santuario de la Virgen de Chamorro en Serantes, y que se incorporaban a la ruta pasando por la parroquia naronesa de Santa María de O Val, cerca de la conocida ermita de Santa Margarida.

Además de esta ruta, la más concurrida y conocida, hay otros caminos de peregrinación entre los que se pueden citar:

- Camino de Cedeira, pasando por San Fiz dé Esteiro, siguiendo por la villa hacia Pontigas, Santa María de Régoa y As Barrosas.

- Camino de Ortigueira por San Adrián de Veiga, ermitas del Socorro Novo en Biduido y Socorro Vello en Meizoso, y Chan da Armada.

- Camino de Cariño, siguiendo la costa por la capilla de San Xiao de Trebo y Garita de Erbeira. 
- Camino de As Somozas, desde la iglesia de Santiago Seré, pasando por el santuario de San Roque do Camiño, ermita de San Xiao dos Osos y Campo de Hospital.

Otro interesante itinerario de peregrinación fue el que siguieron el año 1929 los conocidos miembros del Seminario de Estudos Galegos, Ramón Otero Pedrayo, Vicente Risco y Ben-Cho-Sey. Partiendo de Ourense y siguiendo por Viana do Bolo, Palas de Rei, Lugo y Vilalba llegando a As Pontes desde donde, por Ortigueira, llegaron a San Andrés. Con sus vastos conocimientos de la geografía y la etnografía gallego, Otero Pedrayo dejó escrita una circunstanciada relación del viaje con bonitas ilustraciones de Vicente Risco.

A lo largo de estas antiguas ruta de romeros se conservan interesantes y variados elementos patrimoniales (capillas, castros, cruceros, amilladoiros, fuentes), además del propio camino, en diferente estado de conservación. Para una adecuada protección y puesta en valor de estos bienes patrimoniales y del medio natural en que se inserta así como para la divulgación y conocimiento de tan antigua e histórica ruta es necesaria la pronta creación por parte de la Administración de uno de los novedosos Centros de Interpretación del Patrimonio, complementado con un Aula de la Naturaleza.

\title{
LOS CRUCEROS Y LA SACRALIDAD DE LOS CAMINOS
}

\author{
Estades ante o tempo. Descubrídevos. \\ Recollede os espiritos.... Silencio. \\ Están falando as pedras dos cruceiros. \\ Miguel Anxo Mouriño
}

Desde el origen de los tiempos, los caminos, en su sentido más amplio, añaden a la utilidad de su función como sitio de paso y nexo de unión entre lugares una gran significación dentro del mundo de la simbología y la sacralidad. En particular, el paso del tiempo ha ido empapando a los diferentes y viejos caminos gallegos de un sentido mágico y una intencionalidad sagrada que ha ido quedando grabada de manera material, en especial en las abundante piedra del país gallego, o plasmada de manera inmaterial en forma de un conjunto de tradiciones, ritos y leyendas. 
Remontándonos a los tiempos de la cultura castreña es en Galicia, la menos evolucionada de las comunidades indígenas peninsulares de aquella época, donde se manifiesta una mayor presencia de diferentes divinidades en los caminos y encrucijadas. Estas divinidades persistirán en la posterior época de romanización y en un proceso de sincretismo surgen entonces los Lares Viales.

La cristianización producida a partir del siglo VI, en especial bajo el impulso de San Martiño de Dumio, no consiguió desterrar este sentido mágico, reverencial e incluso su significado de temor, por lo que persistieron una serie de creencias y consiguientes ritos en los caminos y especialmente en lugares singulares de los mismos, como es el caso de las siempre inciertas encrucijadas.

Dos muestras del arte religioso popular relacionadas con este mundo mágico de los caminos son los cruceros y los petos de ánimas, cristianizando antiguos cultos y protegiendo al caminante de los diversos males que pueden esperarle en su ruta, además, caso de los cruceros, de su utilidad material como señales o indicadores de la ruta ayudados de la alta columna que los hace visibles en la distancia y atrae hacia la altura los pensamientos devotos, y de suministro en sus gradas de un lugar de descanso al viajero y de rezo al peregrino.

\title{
LOS CAMINOS, LAS ESTACIONES Y LAS SEÑALES INDI- CADORAS
}

\author{
Axiónllanse os camiños \\ abrazados ao cruceiro, \\ nunha azul eternidade \\ de pedra e ceo. \\ Amado Carballo
}

Desde el punto de vista de contemplación del camino en su concepción intrínseca de itinerario o ruta para desplazarse por el mismo y llegar a un destino, se pueden considerar como sus elementos materiales constitutivos a las propias vías o caminos, las estaciones o lugares de parada y descanso, y las señales o indicadores de la ruta, complementados por otros hitos o elementos auxiliares. 
En lo que respecta al propio camino, que en el caso de las romerías y peregrinaciones es el resultado de una conjunción de antiguas vías romanas, calzadas de época medieval y caminos reales, si bien su trazado ha ido desapareciendo por el paso del tiempo, ayudado muchas veces de un progreso tan necesario como poco respetuoso con el entorno, no se ha perdido totalmente la memoria histórica del itinerario.

Además de las diferentes construcciones que todavía se conservan, de los restos que permanecen de otras y de la contribución de la cartografía antigua (que solamente a partir del siglo XIX aporta la debida precisión), en muchos casos quedan las crónicas de los peregrinos y viajeros que recorrieron la ruta y otras veces pervive una expresiva e indicativa toponimia de lugares a lo largo del itinerario.

Entre los pilares o hitos materiales de estos caminos de romería y de peregrinación, no siempre exclusivos de la ruta pero muchas veces ligados a la misma o nacidos con ella, están los puentes, los hospitales y albergues, las iglesias y capillas, los mercados, hospederías y mesones, las fuentes, los milladoiros, así como los cruceros, oratorios y petos de ánimas.

En este sentido, tanto las procesiones, limitadas a cortos recorridos, como las más largas romerías y peregrinaciones que transitan por los caminos históricos se inscriben en el territorio creando una atmósfera y un espacio sagrado que se manifiesta y refuerza por señales materiales específicas como son los cruceros y las cruces de los caminos.

De esa manera caminos y senderos, sin dejar de realizar su función de favorecer una normal relación humana, se insertan dentro de una especie de reticulado sacral donde los cruceros, en una doble función, por una parte recuerdan al viajero la presencia de un Dios que conforta al peregrino y por otra parte valen de símbolo apotropaico, es decir que sirven para alejar las influencias de los seres malignos en las etapas más solitarias del recorrido.

Dentro de las diversas muestras encuadradas en el arte popular gallego, el crucero constituye una de las obras más enraizadas entre las gentes de la tierra y la más vinculada a la religiosidad y costumbres tradicionales del pueblo, siendo posiblemente la obra más representativa y diferenciadora de la cultura popular, de la que constituye una de sus señas de identidad.

Entre las diferentes causas de levantamiento de los varios miles de cruceros que se conservan a lo largo de Galicia, está el hecho de su función utilitaria de guía y señal de los caminos rurales y sus encrucijadas, donde además cumple la misión de ofrecer al viajero y al peregrino el 
descanso material de sus gradas para el reposo y la meditación, así como el socorro espiritual de su protección.

Una vez desaparecidos a partir de principios del siglo XIX las antiguas señales de término o de jurisdicción (en especial los conocidos rollos o picotas) y exceptuando algunos escasos petos de ánimas y amilladoiros o depósitos de piedras arrojadas por los propios peregrinos, los cruceros son los únicos hitos señalizadores de las rutas de romería y peregrinación que se conservan de tiempos anteriores en su función de guía, compañía y auxilio espiritual.

\title{
LOS CRUCEROS DE LOS CAMINOS A TEIXIDO
}

\author{
Indo para San Andrés, \\ no camiño da romaxe, \\ vexo ó Cristo dos Carrís \\ coidando a miña viaxe \\ Copla popular
}

Las diversas rutas de romería al santuario de San Andrés no constituyen una excepción dentro de los caminos de peregrinación existentes en la Comunidad de Galicia y de la misma forma que ellos se encuentran jalonadas por diversos cruceros levantados en una serie de lugares singulares de los caminos ya citados que atraviesan diversos municipios de las comarcas de Ferrol y Ortegal.

Los cruceros elegidos para presentar en este trabajo son los del monasterio de San Martiño do Couto, lugar de Pena de Embade, ermita de la Virgen de Chamorro, iglesia de Santa María de O Val, capilla de Santa Margarita, cruce de San Pedro de Loira, iglesia de San Martiño de Vilarrube, ermita de San Roque do Camiño, iglesia de Santiago Seré das Somozas, ermita de San Xiao dos Osos, cruce de San Xoán de Casares, iglesia de San Antonio de A Barqueira, iglesia de San Román de Montoxo, iglesia de San Fiz de Esteiro, Cristo de Rebordelo, puente de Cedeira, ermita de San Antonio de Curbeiro, Cristo dos Cadrís, mirador de Garita de Herbeira y santuario de San Andrés de Teixido.

Una singularidad destacable que presenta una parte importante de estos cruceros, siguiendo la normal y sabia característica del arte popular 

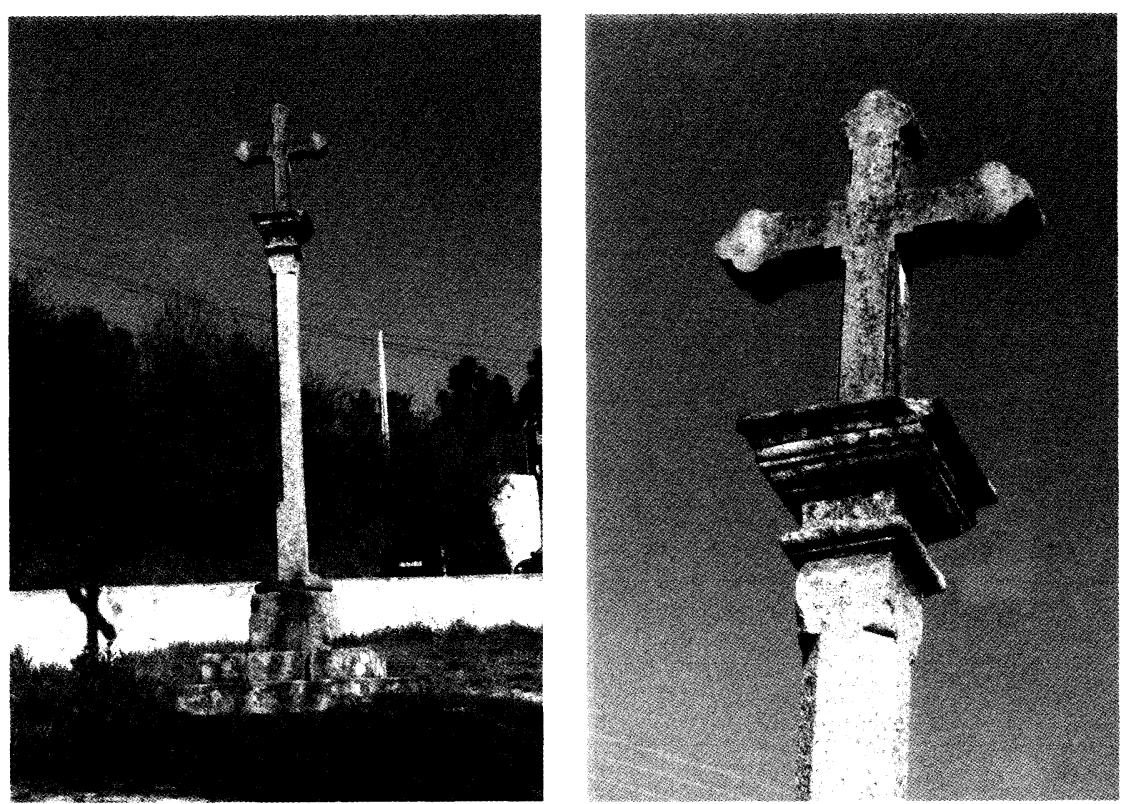

Narón. Monasterio de San Martiño de Xubia o do Couto.

de emplear materiales vernáculos o los más abundantes en la zona, es la de estar elaborados en la conocida piedra serpentina (localmente conocida como toelo o granito de Moeche). Este mineral es más dúctil a los útiles del cantero que la habitual piedra de granito, lo que permite un modelado más fácil de la misma con figuras de formas esmeradas a la vez que su composición veteada le presta unas bonitas tonalidades, variables con la luz solar, pero cuyas características también conducen a un mayor desgaste o erosión debidos al paso del tiempo y a la agresión de los agentes atmosféricos.

Iniciando el recorrido en el municipio de Narón, el primer crucero de la ruta se encuentra situado en el amplio campo de la fiesta contiguo a la hermosa iglesia románica del monasterio de San Martíño de O Couto en Xubia. Es una obra con una inscripción poco legible del año 1787 en el pedestal, el único elemento que parece pertenecer al crucero original erigido en la época en que se construyó la torre barroca del templo.

Sobre la moldura toroidal de remate del pedestal se alza el varal de sección ochavada con biseles en punta de flecha. El capitel es de esquema neoclásico con salientes molduras de filete y de bocel en escalón mien- 

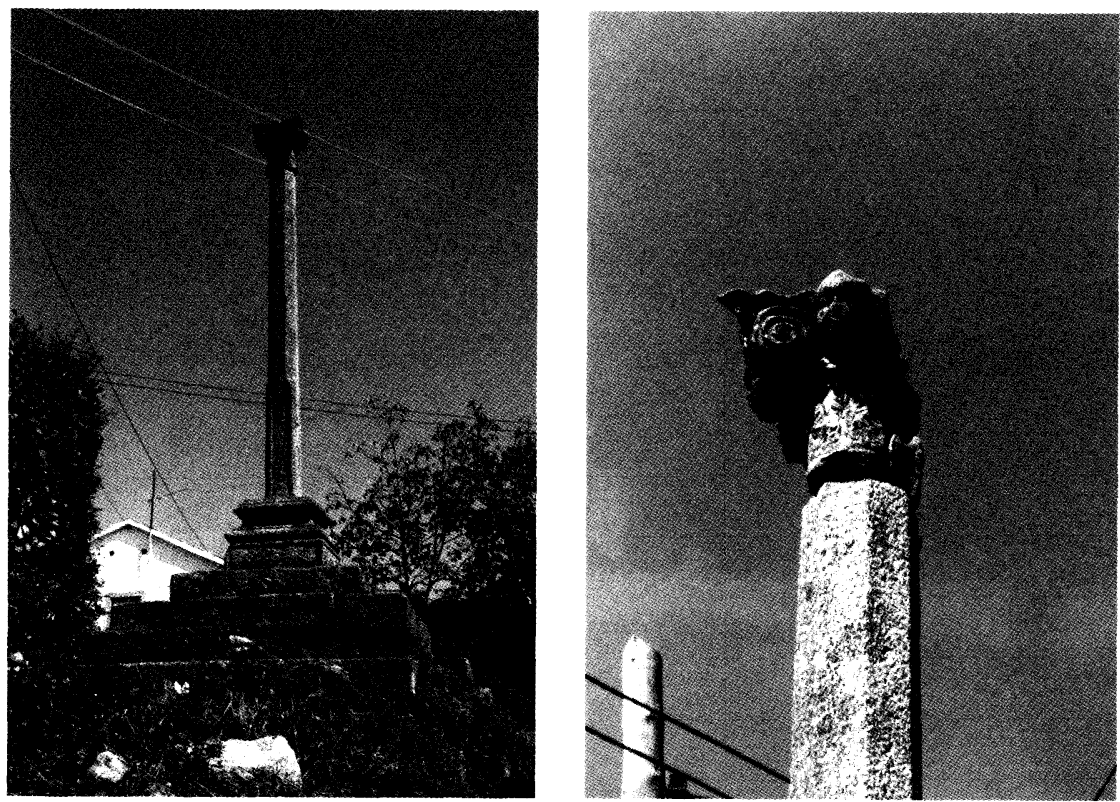

Narón. Pena de Embade.

tras que la vulgar cruz de remate, de forma latina y remates trebolados, está hecha de cemento, sustituyendo la primitiva cruz de bonitas formas.

Continuando el Camiño Vello se encuentra el crucero de Pena de Embade, levantado en un cruce del histórico lugar de dicho nombre. Se trata de una obra llamativamente instalada, de interés y de gran tamaño, pero prácticamente destrozada desde hace tiempo. La alta plataforma escalonada de tres gradas de forma cuadrangular se alza sobre una roca, resto que queda del conjunto en que se encontraba la piedra oscilante que dió nombre al lugar.

Sigue un adornado pedestal de paramentos enmarcados con amplia moldura intermedia en escocia. La columna, esbelta y adelgazada en altura, se inicia con un sobrepedestal cuadrangular, en el que aparecen grabados unos desgastados relieves de símbolos de la Pasión: martillo, clavos, corona de espinas, disciplinas y tenazas. El artístico y deteriorado capitel es de orden compuesto decorado con hojas de acanto, amplias volutas esquinales y sonrientes cabezas de angelotes, habiendo perdido la cruz de remate.

El itinerario que se inicia en la ermita de Santa Comba, en la parroquia ferrolana de Cobas, pasa cerca del conocido santuario de la Virgen de 

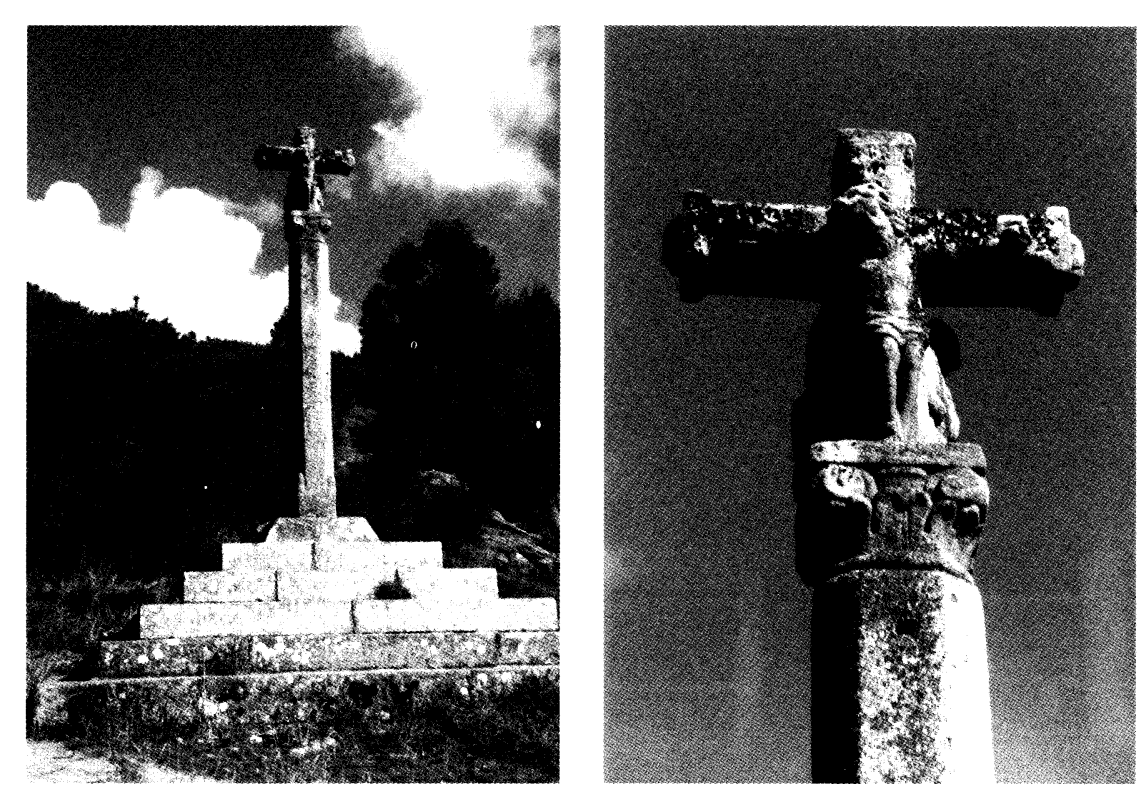

Ferrol. Ermita Virgen de Chamorro.

Chamorro o Nordés, patrona de Ferrol asentada en lugar de viejos cultos, y donde se alza un interesante crucero del siglo XVII, mostrando formas clasicistas en sus imágenes. La plataforma, de cinco escalones de buenos sillares, y el pedestal, corto y de forma trapezoidal, soportan una sólida columna octogonal con bonitos adornos a su inicio.

El capitel es de corta altura y forma cuadrangular, decorado con hojas de acanto y volutas. La cruz, de forma casi griega y de sección ochavada remata sus extremos con semiesferas. Las imágenes son las de Cristo con melena y corona de espinas, las manos semicerradas y cabeza caida a la derecha, mientras apoya sus pies en el capitel. La Virgen de la Piedad del reverso está tallada en una composición triangular de amplios volúmenes y muestra al Hijo en su regazo.

Ya en la parroquia naronesa de Santa María de O Val se encuentra un airoso crucero situado en un extremo del atrio de la iglesia parroquial. El crucero se levanta sobre un alto pedestal de dos cuerpos, el inferior de forma cuadrangular con sus caras enmarcadas y el superior de caras alabeadas y una alcancía metálica de limosnas al frente. La espigada columna se inicia y remata de forma cuadrangular siendo de sección cilíndrica en su tramo intermedio.

«CUADERNOS DE ESTUDIOS GALLEGOS», Tomo L, Fascículo 116, Santiago 2003. 

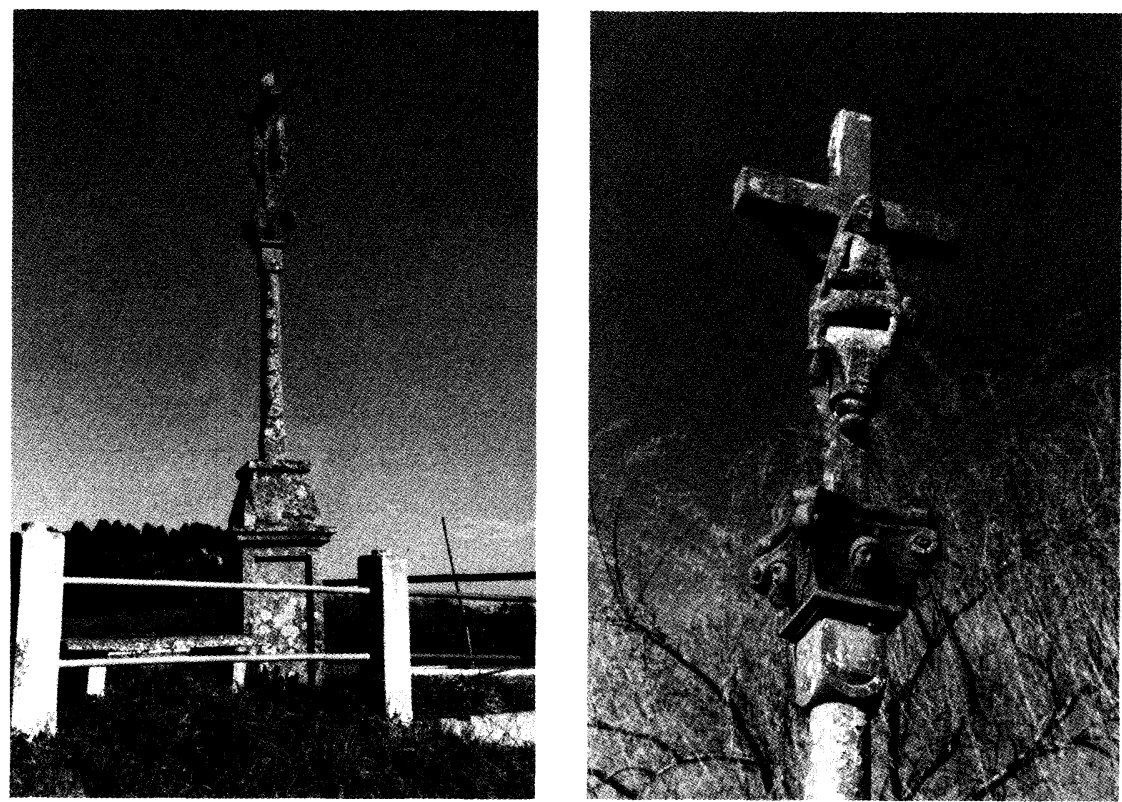

Narón. Santa María do Val.
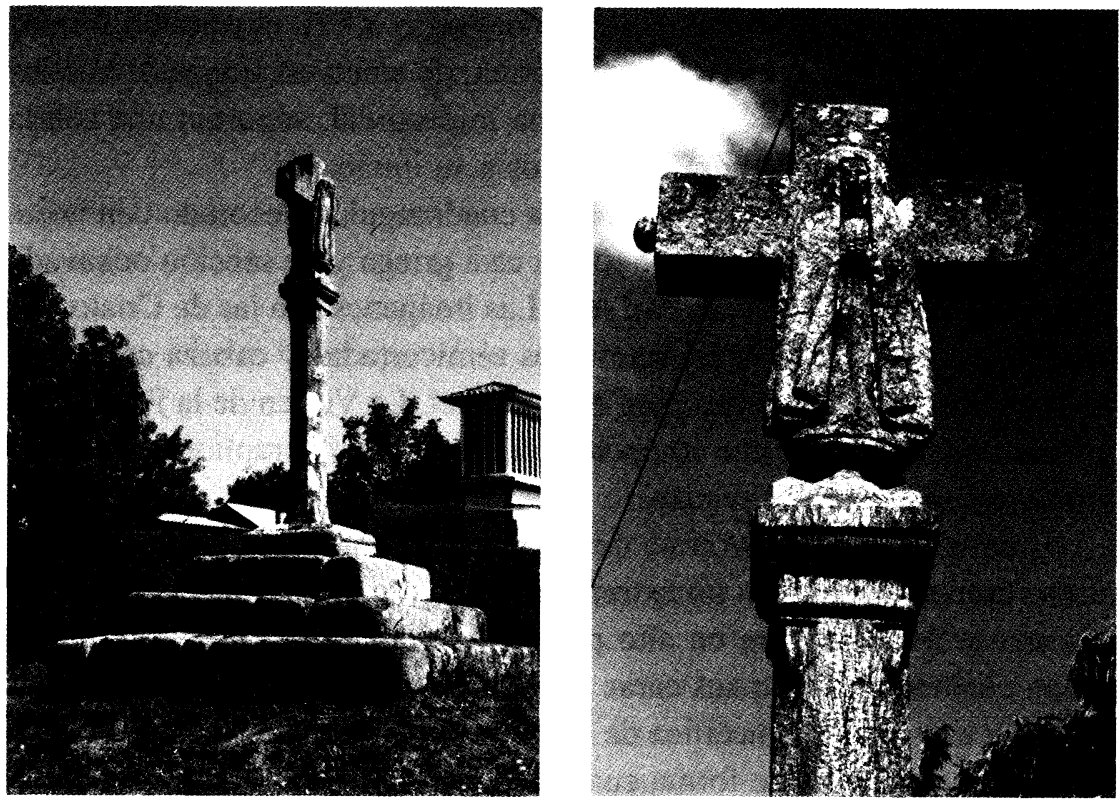

Narón. Santa Margarita do Val.

«CUADERNOS DE ESTUDIOS GALLEGOS», Tomo L, Fascículo 116, Santiago 2003. 
El capitel es elegante decorado con cabezas aladas de querubines y volutas esquinales. Una cruz de palos lisos y de sección cuadrada porta dos imágenes de formas esbeltas y longilíneas. Cristo aparece descolgado del madero con sus piernas flexionadas mientras que la Virgen de la Piedad aparece colocada de forma frontal y estática mostrando al Hijo de pequeño tamaño en sus brazos.

En un cercano desvío se encuentra la antigua capilla renacentista de Santa Margarita con puertas de arcos conopiales y escudos blasonados de los Andrade. El crucero situado en su campo es una obra interesante y de formas arcaicas, elaborada de piedra serpentina, excepto la plataforma y pedestal, hechos de granito y que posiblemente pertenecieron a un crucero anterior. La columna es relativamente corta, de sección ochavada con remates de bellota. El capitel es de forma cuadrangular con molduras de caveto y bocel.

La cruz, de gruesa sección cuadrangular, remata sus extremos con semiesferas. Las imágenes son las de Cristo bajo un gran letrero en pergamino de INRI, en mal estado faltándole las piernas, cabeza ladeada a la derecha, marcada anatomía y paño de pureza con un abultado bucle, y la de la Virgen, esculpida con menos bulto y más detalle, vestida con un amplio manto, en postura frontal de manos en actitud orante y colocada sobre una peana moldurada en forma de copa invertida.

Siguiendo por tierras del municipio de Valdoviño, el crucero de Loira está situado en el lugar de Calvario, en un cruce próximo a la antigua e interesante iglesia de San Pedro. Es una obra de piedra serpentina mostrando las características típicas de los canteros de la escuela de Moeche que a fines del siglo XIX trabajaron en la comarca. Está adosado al muro de una finca sobre un pedestal de caras alabeadas en el que lleva grabada una inscripciòn de erección. La columna empieza de sección cuadrada, pasa pronto a forma cilíndrica y remata con un doble collarín de la misma forma.

El capitel es el clásico de esquema jónico gallego decorado con volutas esquinales y cabezas aladas de querubines, de formas esquemáticas y de poco relieve. La cruz de palos cilíndricos lleva las imágenes de Cristo de buen canon, tallado separado de la cruz y con sus manos semicerradas, $\mathrm{y}$ de la Virgen en postura orante sobre peana de formas geométricas y cubierta con un largo manto desde la cabeza, ambas efigies de formas simples y con pocas concesiones a los detalles anatómicos. 

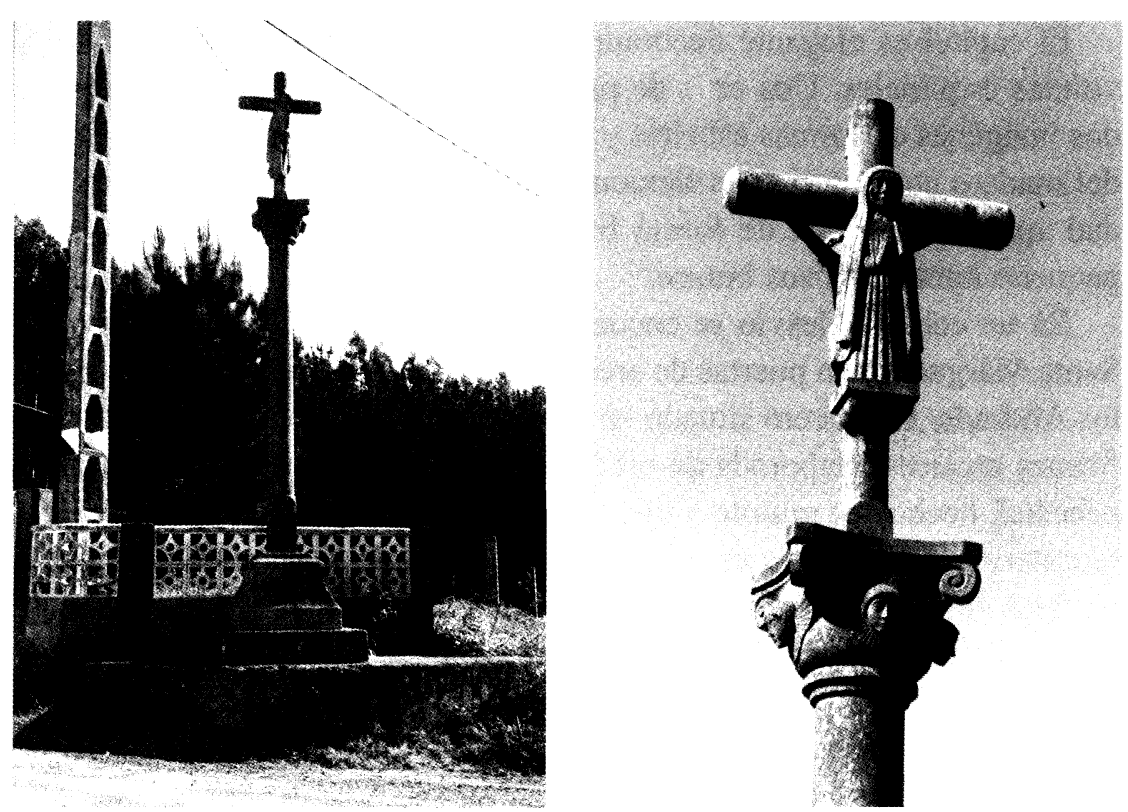

Valdoviño. San Pedro de Loira.

El crucero parroquial de Villarrube está al borde de la carretera, dominando la iglesia de San Martiño. Es una obra del año 1830, elaborada de granito y serpentina, muy desgastada en su conjunto. La plataforma es de tres gradas y el pedestal de forma prismática se adorna con un rebaje mediacaña en su alrededor, llevando una leyenda ilegible del citado año. La columna es de sección cuadrada en su tercio inferior y de sección octogonal el resto, mientras que el voluminoso capitel es de esquema corintio, con un cuerpo bajo de hojas vegetales de palmeta y un cuerpo alto decorado con cabezas aladas de querubines y volutas esquematizadas.

La cruz es de palos ochavados portando una imagen de Cristo muy erosionada, bajo cartela de INRI, crucificado con manos cerradas, rostro de facciones borradas y amplio paño con nudo grande atado a la derecha, y una imagen de la Virgen de bulto redondo, colocada en posición frontal sobre el capitel, vestida de amplia capa y faldón y con los brazos colocados en aspa sobre el pecho.

Otro ejemplar interesante se yergue en el municipio de As Somozas, frente a la conocida capilla de San Roque do Camiño, lugar de renombrada romería en honor de su patrón. La capilla posee una curiosa fuente 

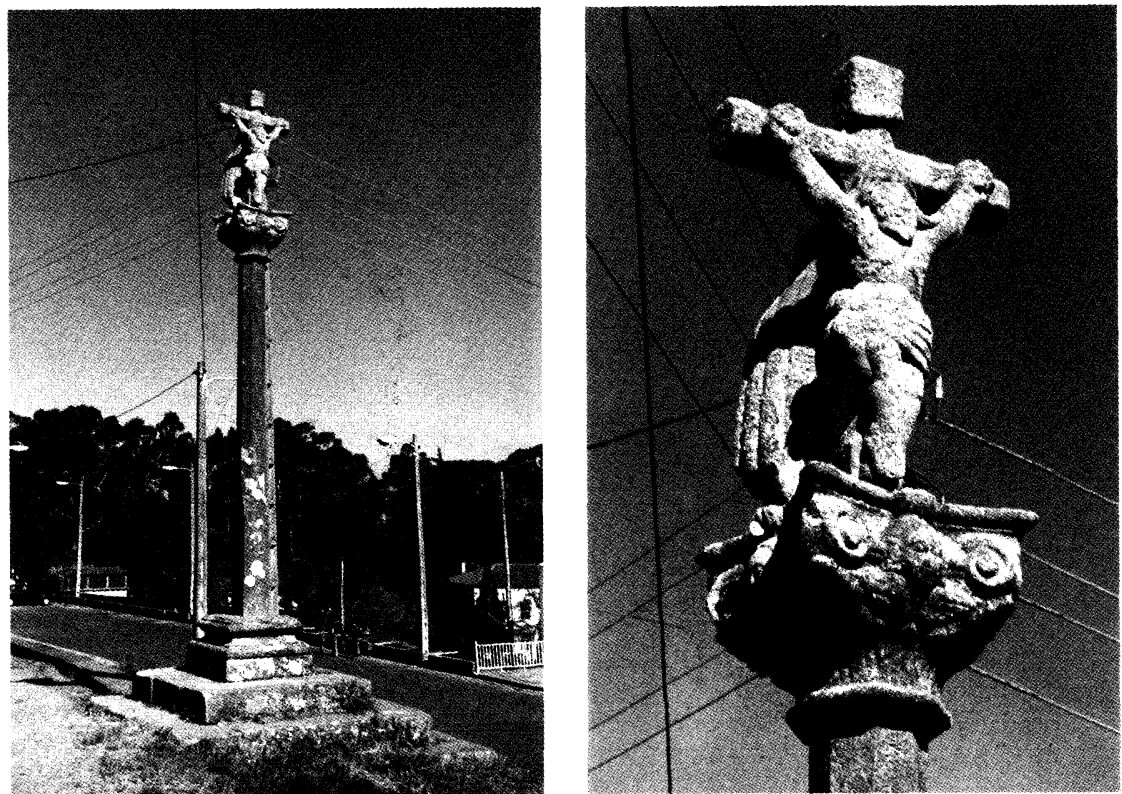

Valdoviño. San Martiño de Villarrube.
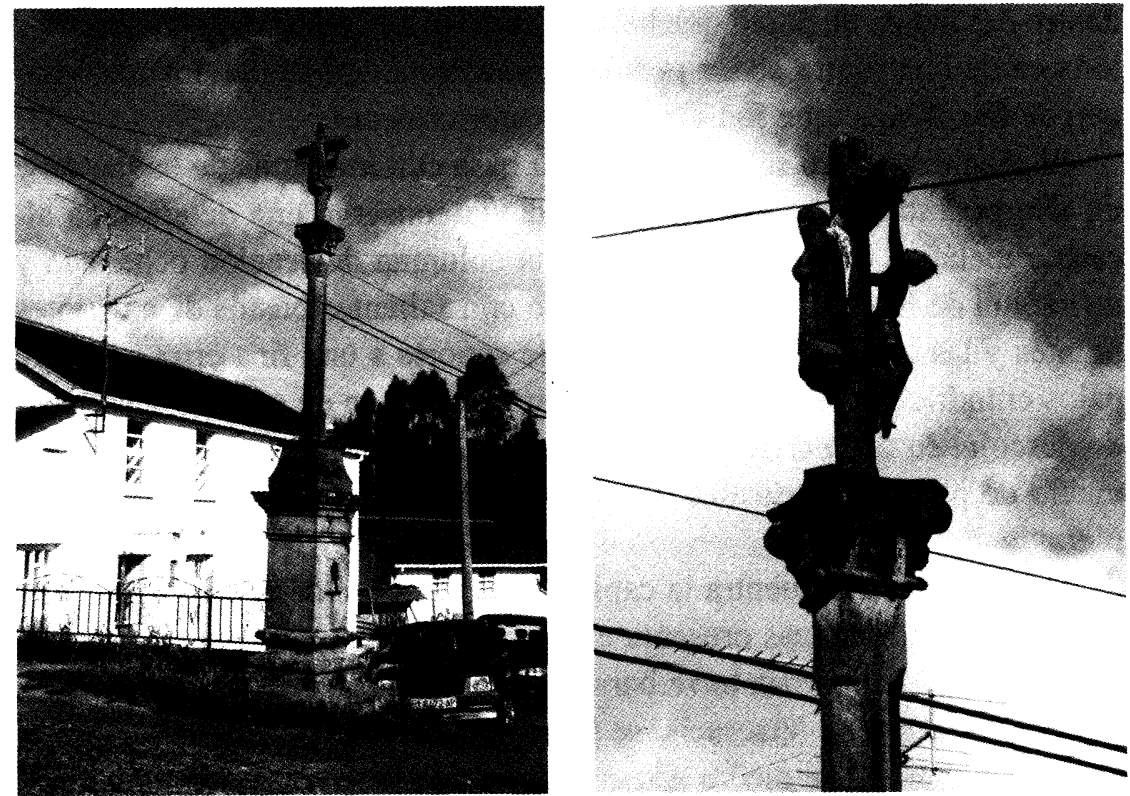

As Somozas. San Roque do Camiño.

«CUADERNOS DE ESTUDIOS GALLEGOS», Tomo L, Fascículo 116, Santiago 2003. 

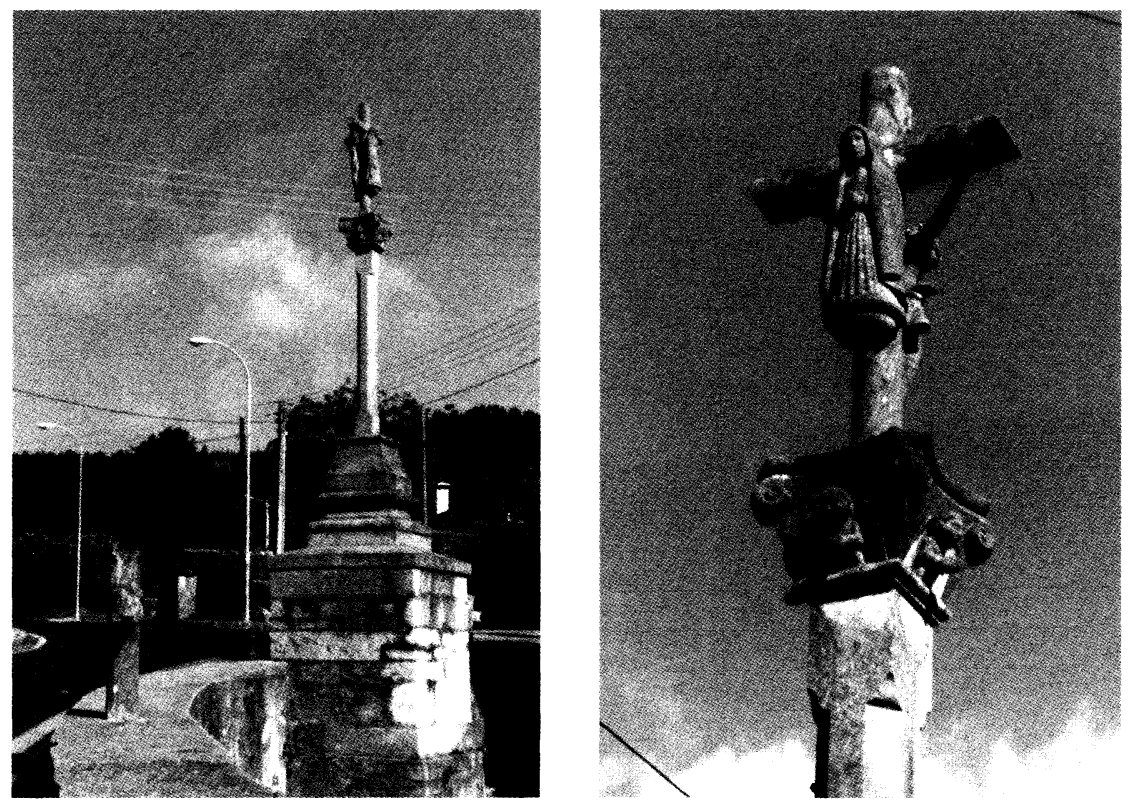

As Somozas. Santiago Seré.

dentro del lienzo de pared que hace de testero. El chorro del agua nace de la boca de una figura con aspecto de mascarón, bendecido por una imagen de San Roque que fue colocada posteriormente.

El esbelto crucero se alza sobre una basa con molduras de baquetón y un alto pedestal, cuyo cuerpo bajo todavía conserva una deteriorada alcancía metálica de limosnas. Una corta columna de sección ochavada y un capitel de formas clásicàs, decorado con salientes bustos de angelotes orantes y las clásicas volutas, sirven de soporte a una fina cruz latina de palos cilíndricos con imágenes de Cristo, coronado de espinas y esculpido descolgado de la cruz, y de la Virgen de Dolores, vestida con túnica y manto de pliegues verticales y representada en postura orante de manos juntas.

Muy cerca, se encuentra la capital municipal donde la iglesia de Santiago Seré das Somozas presenta en su fachada una policromada imagen del Apóstol y una airosa torre barroca. En su atrio, rodeado de una serie de cruces pétreas de Viacrucis, se levanta el crucero parroquial, como el anterior elaborado de piedra serpentina, colocado sobre una amplia basada de sillares encintados 

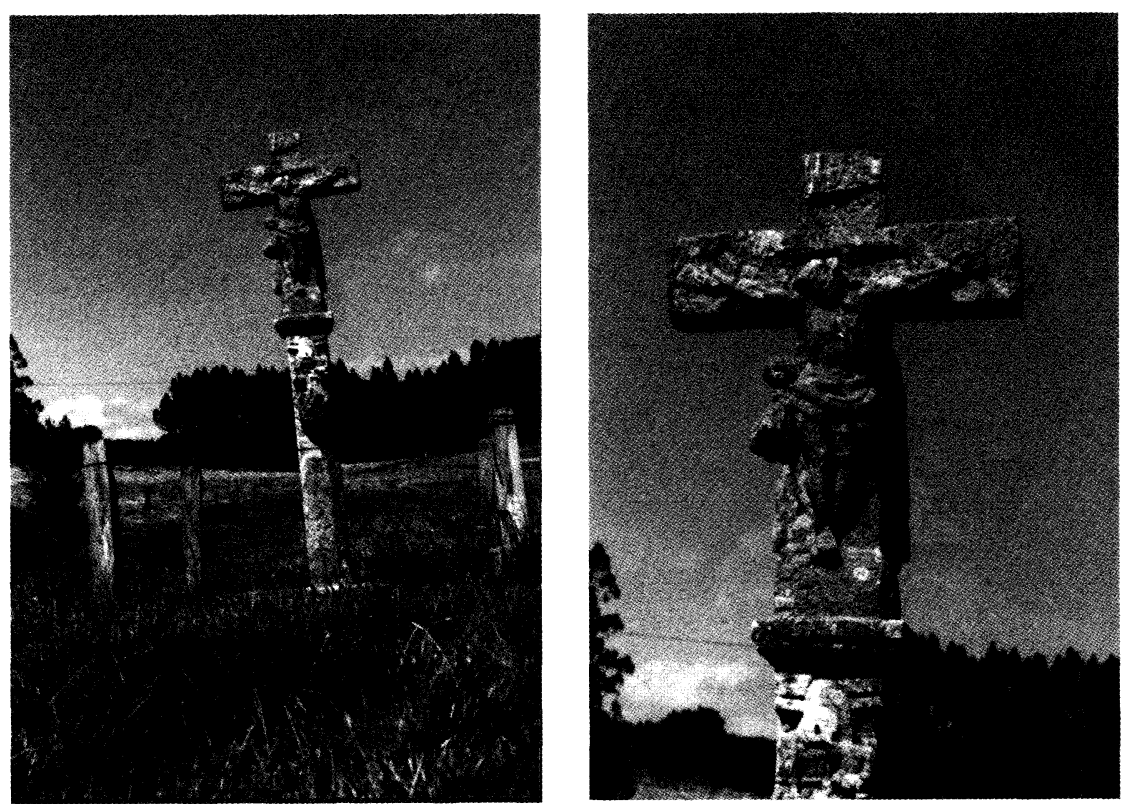

Moeche. San Xiao dos Osos.

El amplio pedestal, de esquema toscano con molduras boceladas y de media caña, sirve de soporte a una corta columna de marcados biseles en punta de flecha y un capitel de formas similares al del anterior crucero. De igual manera la cruz de forma latina y sección circular se adorna con semejantes imágenes de formas suaves y talla esmerada de Cristo crucificado bajo letrero de INRI, con su anatomía bien marcada, y de la Virgen Dolorosa vestida de manto desde la cabeza y colocada sobre una peana de forma acopada.

Entrando en el municipio de Moeche el camino pasa por la ancestral ermita de San Xiao dos Osos en Labacengos, modesto templo que ya era conocido el siglo XIII. Sobre la pared posterior se conserva el escudo de Oseira, mientras que a la puerta de la ermita se encuentran dos sarcófagos antropoides.

En un campo cercano, apenas protegido por un tosco armazón de madera, se encuentra el crucero. Obra incompleta y en mal estado, revestida de líquenes, rústica y de cierto encanto, en su corta columna muestra tallada al frente una mutilada figura de formas genuinas de San Antonio. Un estrecho capitel de molduras rectas recibe una sólida cruz de 

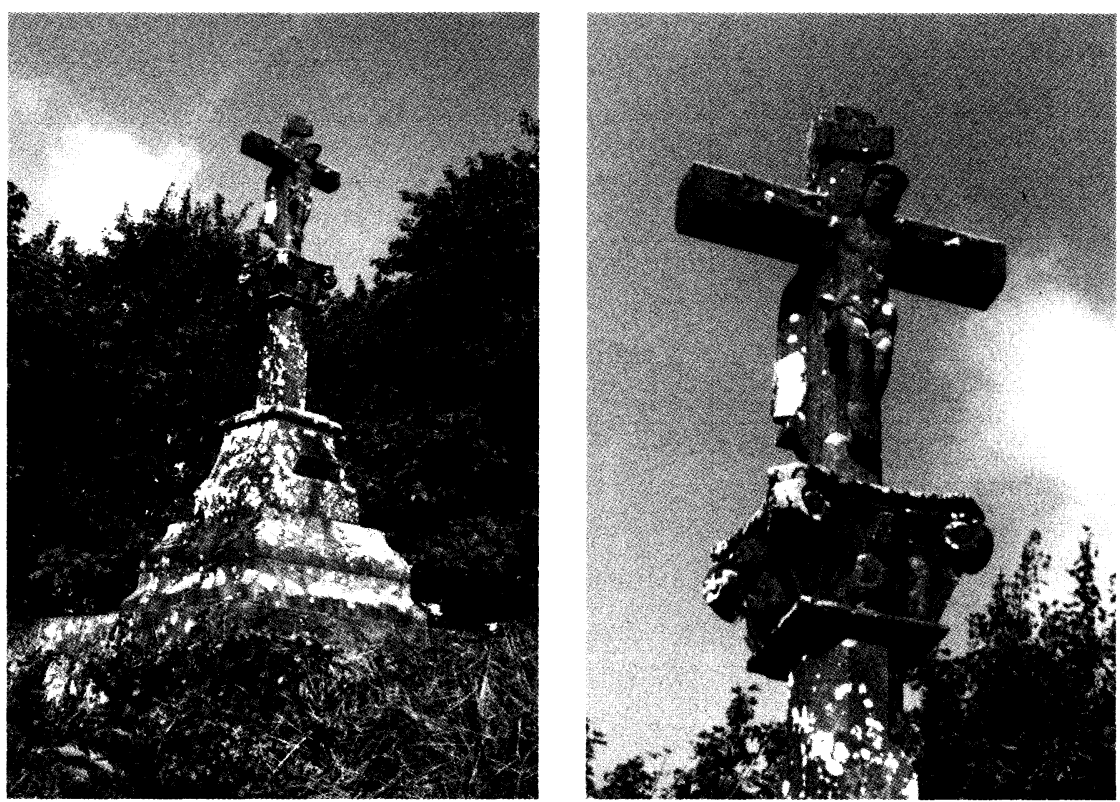

Cedeira. San Xoán de Os Casás.

sección cuadrangular con imágenes arcaicas y deterioradas de Cristo, de formas amplias, clavado con manos abiertas y con un paño de pureza de grueso nudo, y de la Virgen en una labra de poco detalle y escaso relieve.

La ruta atraviesa el municipio de Cerdido donde se encuentra la iglesia parroquial de San Xoán de Os Casás. En un alto talud cercano se levanta un curioso crucero sobre un amplio pedestal de dos cuerpos, el inferior con doble moldura de escocia y el superior de la clásica forma de la zona con caras alabeadas y una alcancía de limosnas. La columna es de muy poca altura con sus aristas biseladas.

Lleva un aparatoso capitel decorado con mediorrelieves de bustos de ángeles alados. La cruz de forma latina y palos cuadrados lleva al frente buenas imágenes de Cristo bajo letrero de INRI, de anatomía marcada con manos abiertas y pies clavados tradicionalmente, y de la Virgen de Dolores, vestida de túnica y manto hasta los pies, de menor tamaño.

Sin dejar el municipio de Cerdido se encuentra la iglesia de San Antonio de A Barqueira. Su crucero parroquial, situado dentro del estrecho

«CUADERNOS DE ESTUDIOS GALLEGOS», Tomo L, Fascículo 116, Santiago 2003. 


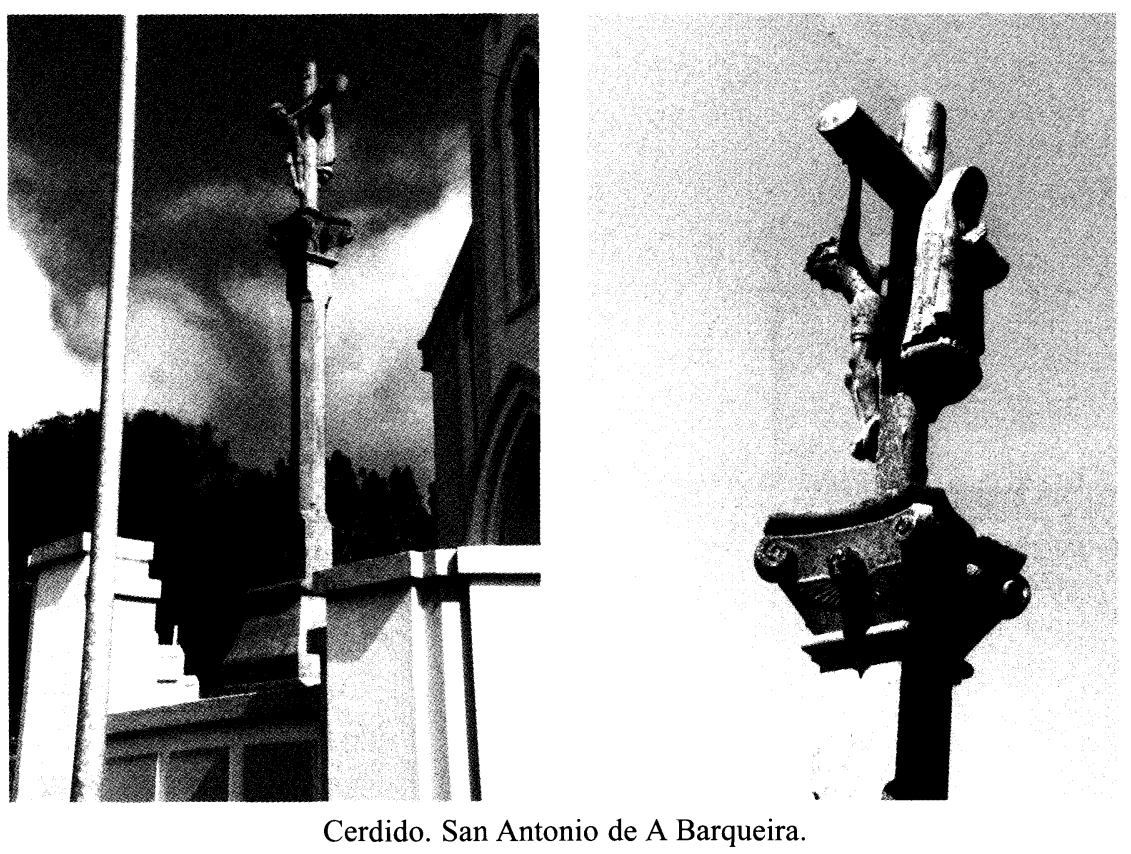

atrio del templo, lleva el habitual pedestal de forma tronco-prismática con caras alabeadas, mientras que la columna es de sección ochavada con biseles en punta de flecha. El bonito capitel de forma cuadrangular y esquema jónico en su variante gallega, se decora con cabezas aladas de querubines en las caras y con volutas en las esquinas, y remata de un ábaco curvilíneo.

La cruz es de forma latina y los palos son cilíndricos con remates cortados a bisel. Las habituales imágenes de Cristo y de la Virgen de Dolores están talladas con cierto primor, el Cristo coronado de espinas y separado de la cruz, y la Virgen, vestida de túnica de pliegues y manto volado, colocada en posición frontal de manos juntas y actitud hierática.

En el municipio de Cedeira un nuevo crucero se yergue frente a la iglesia parroquial de San Román de Montoxo. Colocado sobre una basada cuadrangular de cemento, está elaborado de piedra serpentinita como los anteriores, dotado de un típico pedestal tronco-prismático y una columna de sección ochavada con marcados biseles.

«CUADERNOS DE ESTUDIOS GALLEGOS», Tomo L, Fascículo 116, Santiago 2003. 

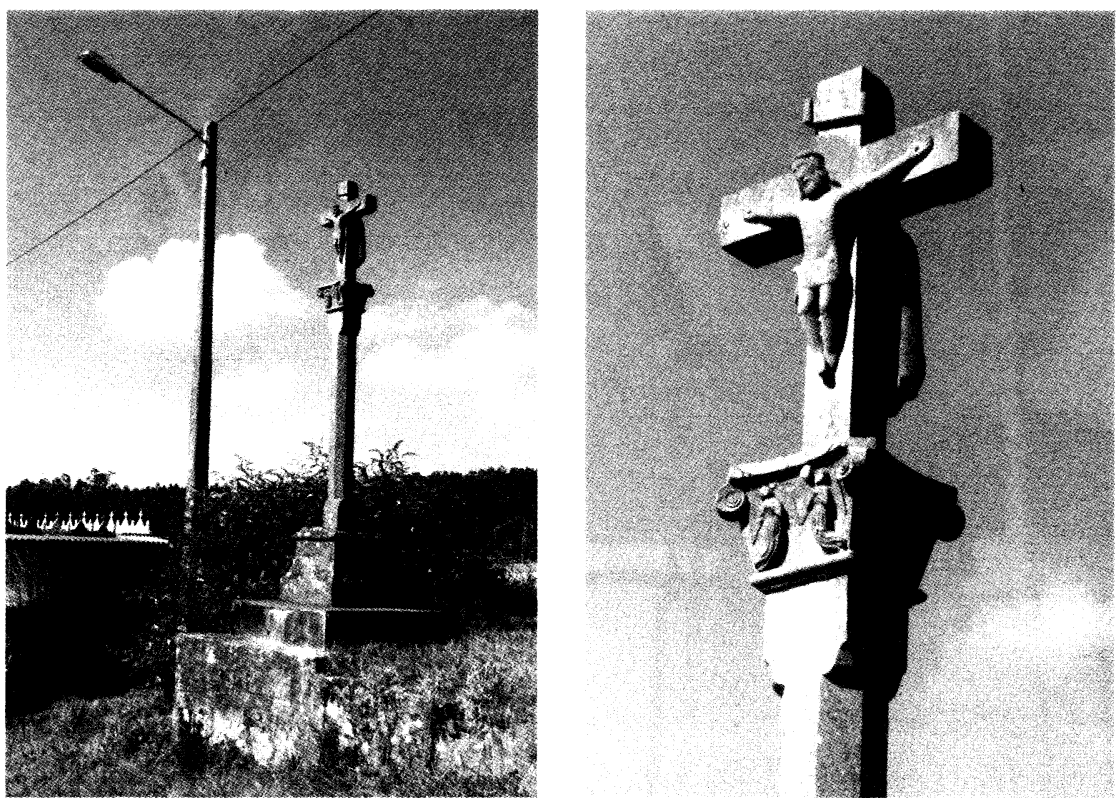

Cedeira. San Román de Montoxo.

El capitel de forma cuadrangular se adorna con las clásicas volutas esquinales y en cada una de sus caras aparecen tres mediorrelieves de pequeños ángeles representados de rodillas. La cruz es de forma latina con palos cuadrangulares y las acostumbradas imágenes de Cristo y la Virgen son de talla corta y formas esquemáticas, con efigies poco resaltadas y de poco detalle, esculpidas pegadas al madero.

Cercano se encuentra el crucero de Esteiro, situado en el elevado atrio de la iglesia de San Fiz. Se trata de una obra igualmente realizada en serpentinita o piedra de Moeche, modelo y prototipo de la escuela del cantero Antonio Rodríguez de Moeche. Su amplio pedestal es de forma tronco-prismática con caras alabeadas y está colocado sobre los muros del atrio con una inscripción de patrocinado y hecho a devoción de seis donantes el año 1902.

La columna es de típica sección cuadrada-ochavada-cuadrada y el capitel es de formas escuetas, decorado con volutas en las esquinas y cabezas de ángeles en las caras, rematado de ábaco curvilíneo. Se corona con una cruz de sección circular y remates biselados oblicuos que lleva imá- 

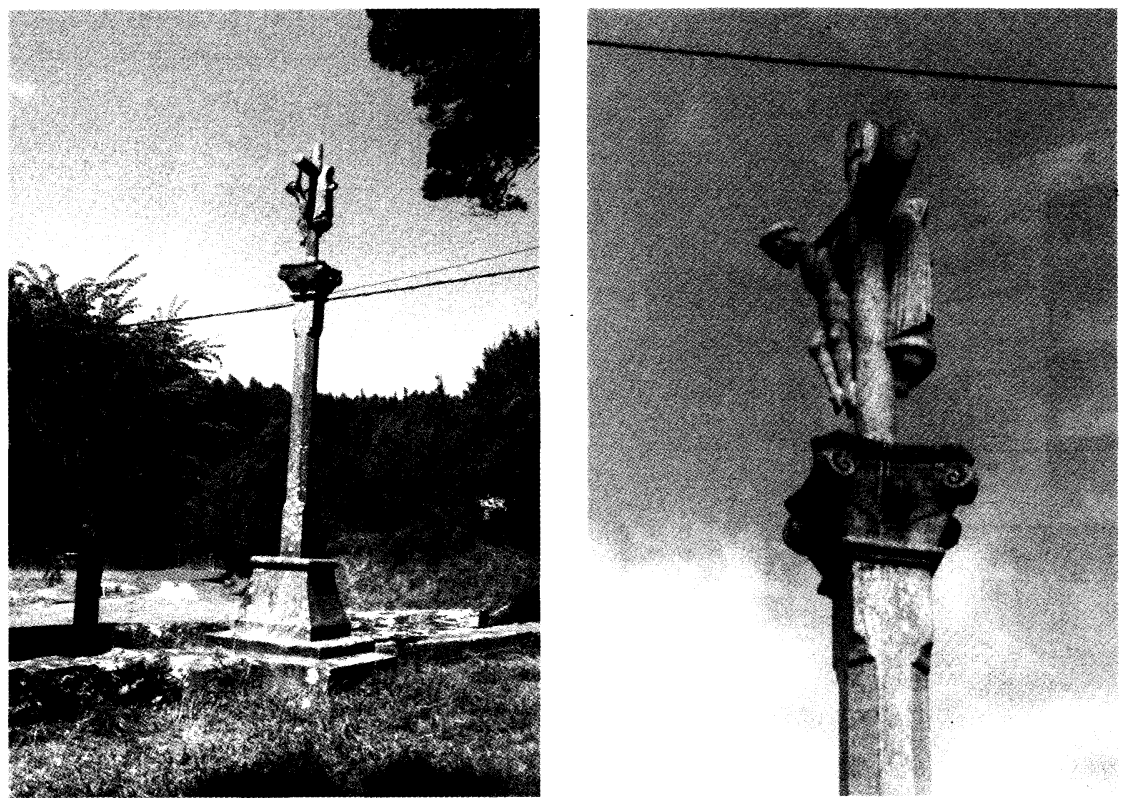

Cedeira. San Fiz de Esteiro.

genes bien trabajadas de Cristo bajo letrero de INRI, esculpido separado del madero, y de la Virgen en actitud orante y de formas tradicionales, representada con menor altura y preeminencia que la efigie del anverso.

La entrada en la villa por el puente sobre el río Condomiñas se adorna con un crucero moderno y de buen tamaño colocada en un campillo lateral. Se trata de un ejemplar poco tradicional, tanto por los materiales empleados, granito muy fino para la parte inferior y cemento para el remate, como por sus características formales. Obra de carácter modernista sin abandonar la tradición, está colocada sobre una plataforma de tres gradas $\mathrm{y}$ un pedestal cuadrangular.

La sólida columna cilíndrica se inicia con un sobrepedestal moldurado en forma de basa ática y termina con un collarín de bolas. El capitel circular se decora con una corona de espinas alrededor y se remata con un ábaco de pivotes cúbicos. La cruz de sección rectangular y forma recrucetada porta unas imágenes de Cristo con la cabeza mirando al cielo, de marcada anatomía y con sus pies sobre un supedaneo, y de la Virgen de formas movidas y vestida de ropaje suelto, ambas de buenas proporciones y ponderado naturalismo. 

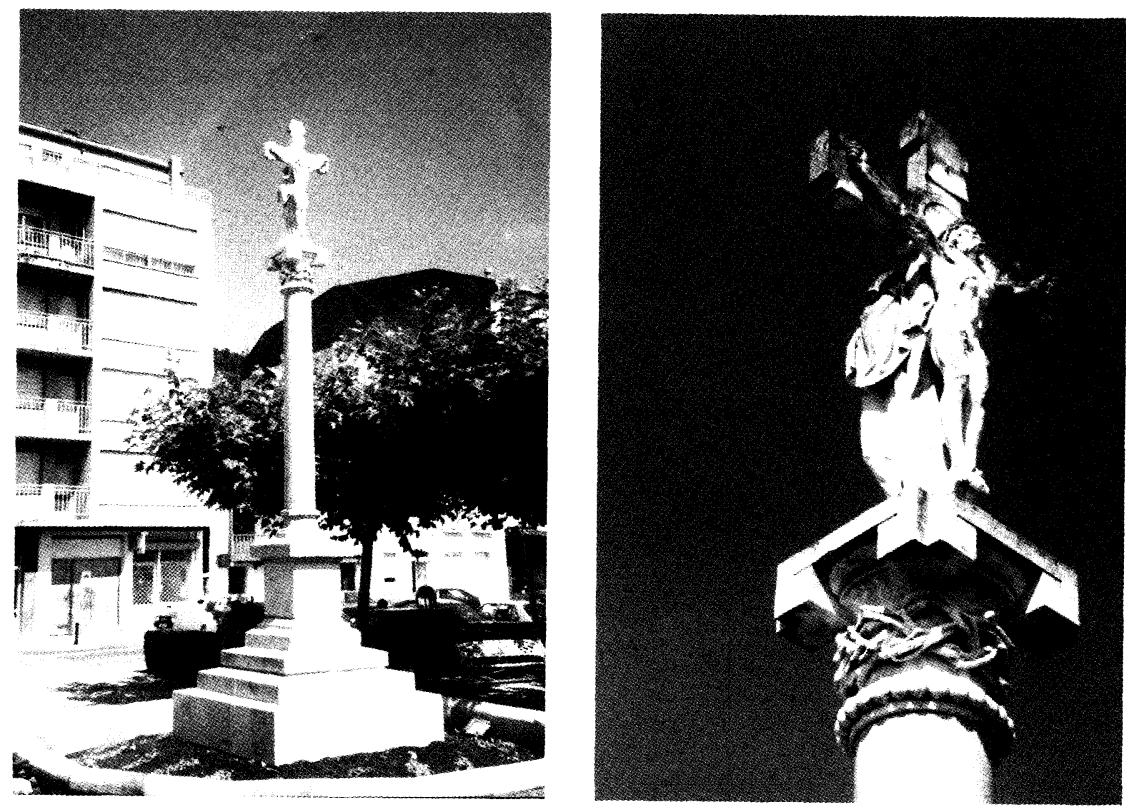

Cedeira. Puente río Condomiñas.

Dentro del casco antiguo de Cedeira se encuentra el conocido y entrañable crucero conocido como Cristo de Rebordelo, obra del siglo XVIII. Situado hoy en la Rúa da Cruz posiblemente estuvo adosado originalmente a la desaparecida puerta de la que tomó su nombre. El hecho de mostrar únicamente imágenes al frente abunda en esa posible ubicación.

Realizado en piedra serpentina muy veteada, se asienta sobre una basta plataforma cuadrangular con una corta y gruesa columna biselada de remates de bellotas. Sobre el sencillo capitel de molduras rectas se apoya una Virgen en postura orante, vestida de túnica de pliegues, con formas rechonchas y marcado carácter popular. En la grande y sencilla cruz de palos cuadrangulares aparece una imagen de Cristo de manos abiertas, tapado con amplio perizoma y bajo cartela de INRI, de formas arcaicas y de amplio desgaste.

Dominando una magnífica panorámica, camino de los impresionantes paisajes de Punta Candieira, se encuentra la ermita de San Antón de Corveiro, lugar de devoción popular y de concurrida romería. En su extenso campo está colocado desde hace algunos años un histórico, sólido y lla- 

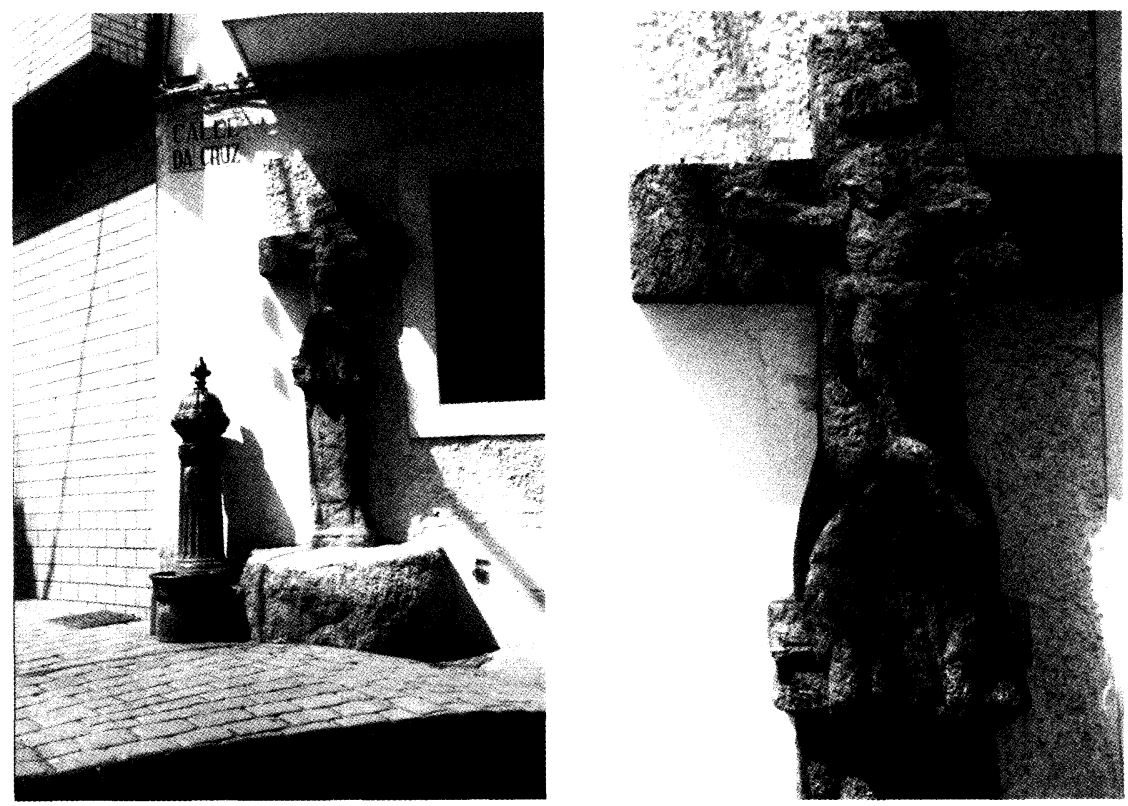

Cedeira. Cristo de Rebordelo.
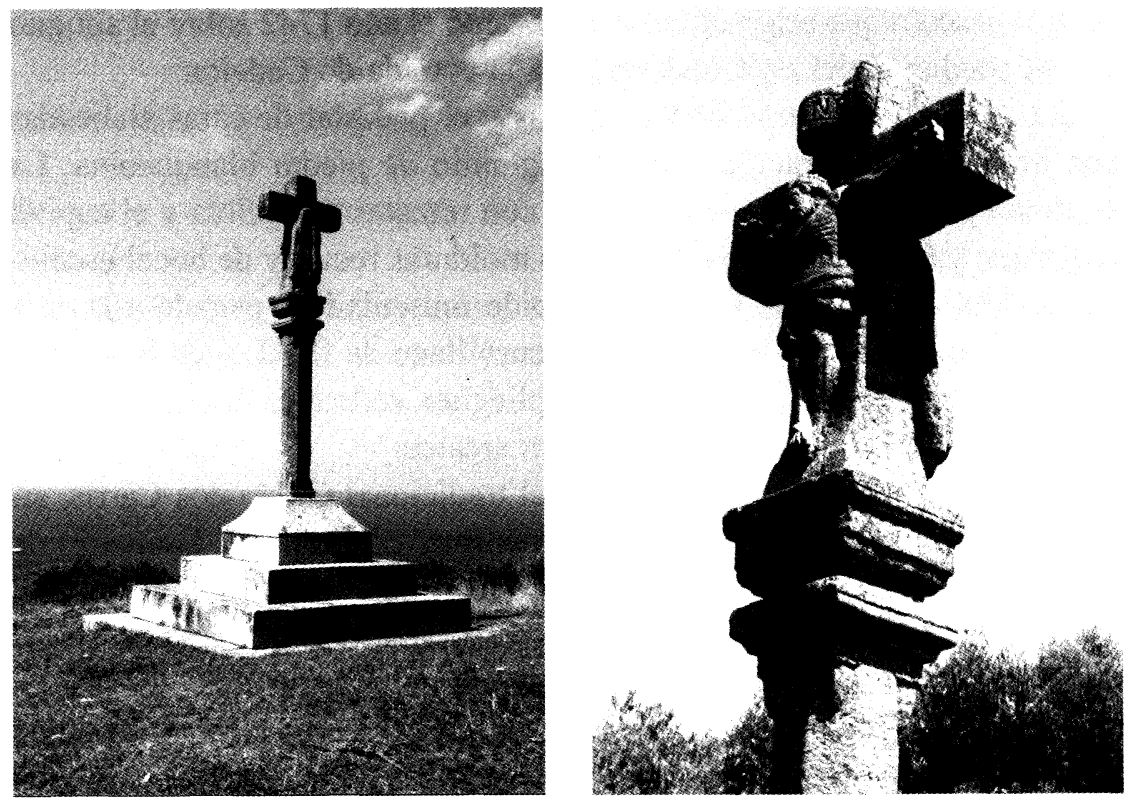

Cedeira. San Antón de Corveiro.

«CUADERNOS DE ESTUDIOS GALLEGOS», Tomo L, Fascículo 116, Santiago 2003. 

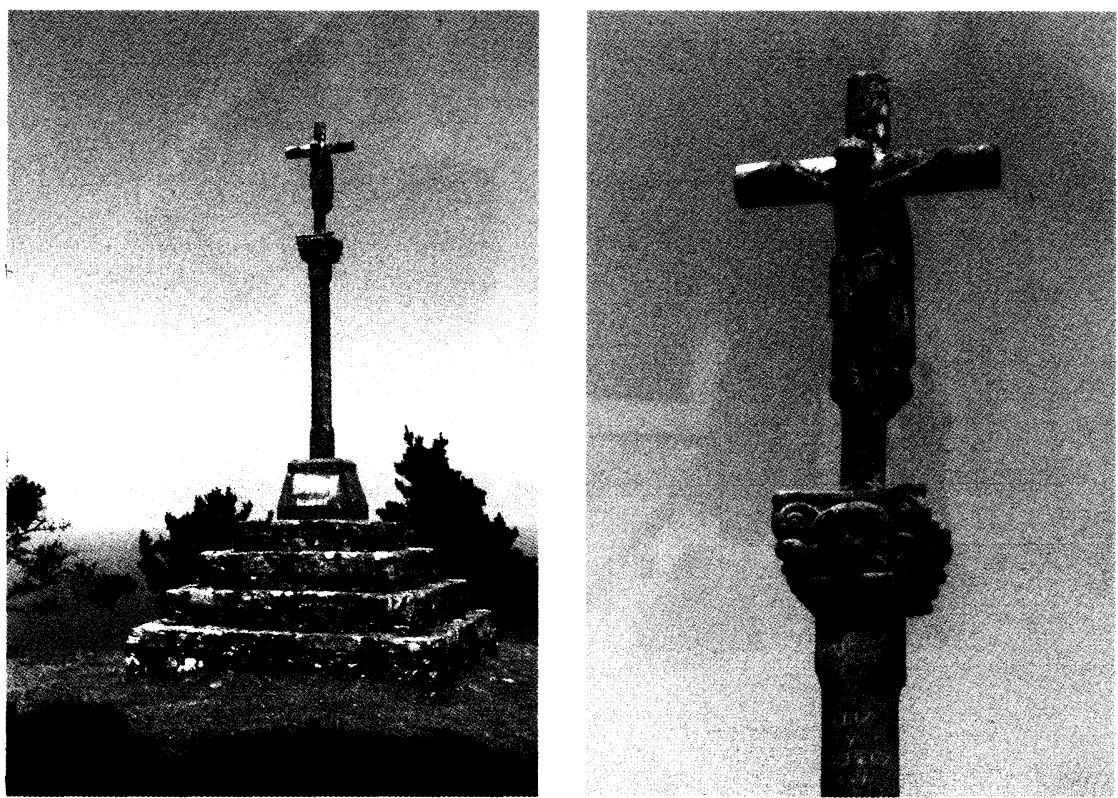

Cedeira. Cristo dos Carrís.

mativo crucero que originalmente se levantó el año 1742 sobre el antiguo puente medieval del río Condomiñas a la entrada de Cedeira.

La amplia plataforma de tres gradas y el pedestal de caras alabeadas son de nueva elaboración a base de granito de piedra blanquecina. La columna presenta un suave ochàvado con remates en bellota y el capitel es grande y trabajado, a base de varias molduras rectas y de bocel escalonadas. Las imágenes de Cristo, esculpido musculado y pegado a la cruz con larga melena bajo amplio letrero curvilíneo de INRI, y de la Virgen, tocada de amplio manto y faldón de pliegues verticales del que asoman los pies, son de calidad y de figuración arcaica.

El siguiente crucero de la ruta es el tradicional Cristo dos Carrís, situado en pleno Camino de los Romeros, muy cerca ya del Santuario de San Andrés. Se trata de una obra de corte popular, la más conocida del camino de peregrinación, y en cuyas proximidades se levanta uno de los amilladoiros o montones de piedras dejadas por los romeros.

El Cristo dos Carrís se alza sobre una dominante plataforma de cinco escalones, hecha de mampostería de pizarra. El pedestal, de forma tronco prismática y caras lisas, y la columna, de sección cuadrada-ochavada- 

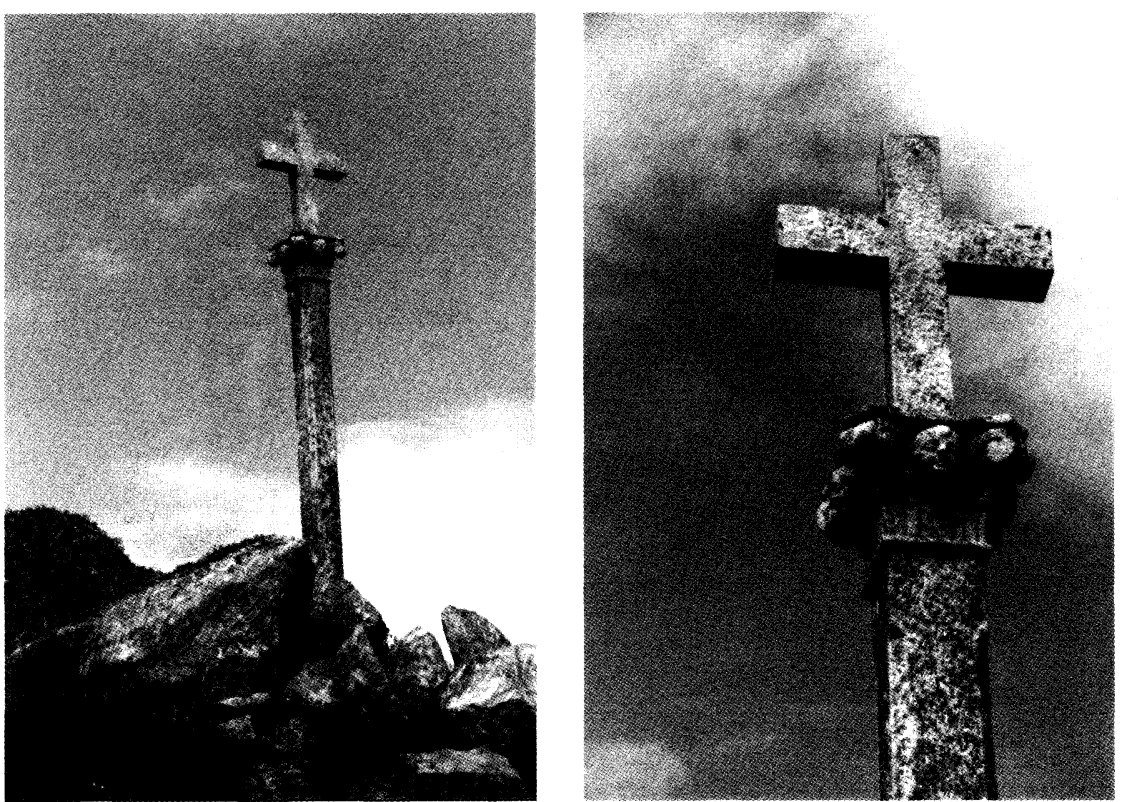

Cedeira. Mirador de la Garita de Herbeira.

cuadrada, son de piedra serpentina. El capitel es un buen y artístico ejemplar de granito, posible obra de un crucero anterior, y se decora con conchas barrocas y cabezas orladas de angelotes. De nuevo la cruz de palos circulares y las imágenes de figuración realista, modelación esbelta y formas clásicas de Cristo y la Virgen de Dolores son de piedra serpentina.

Antes de bajar al santuario de San Andrés de Teixido un desvío lleva al espectacular mirador de la Garita de Herbeira, donde se levanta un crucero sobre las altas rocas del promontorio. Es una obra reciente, de piedra granítica y estilo moderno, estando emplazado de manera visible y llamativa.

La plataforma de dos uscalones está colocada a continuación de la escalera de subida y sobre ella va el pedestal de forma prismática con los bordes altos rebajados. La columna es de sección cuadrangular con ligeros biseles en sus aristas. El capitel, de forma cúbica, lleva una decoración clásica con mofletudos angelotes, sobresalientes volutas y decoración vegetal. La cruz, de palos cuadrados y lisos, es muy sencilla y desmerece el conjunto. 

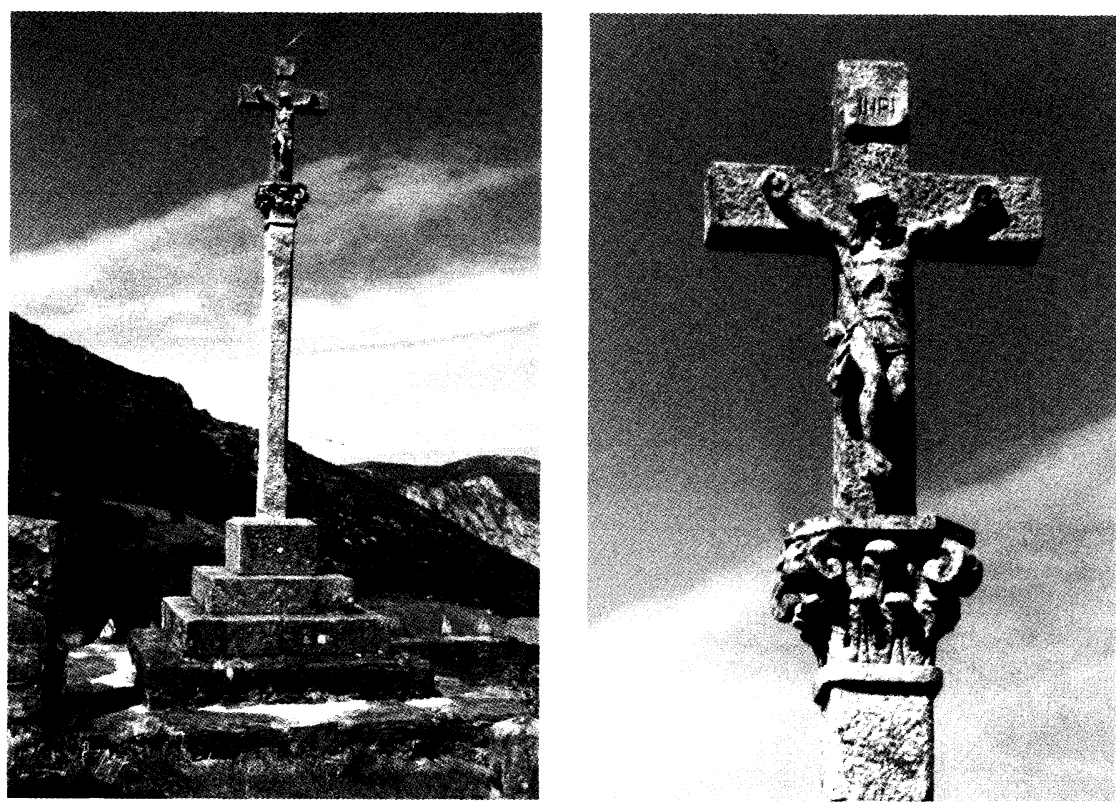

Cedeira. San Andrés de Teixido.

Ya en el campo frente al santuario de San Andrés se erige el último de los cruceros de esta ruta, un ejemplar sencillo y de formas tradicionales que se levanta sobre una plataforma mixta de gradas de granito y de pizarra. El resto de los elementos del crucero son de piedra de granito.

El pedestal de forma cuadrangular con caras lisas y aristas en chaflán mientras que la columna es de sección ochavada. El capitel, de forma tronco-prismática invertida se adorna con volutas altas y una hilera de hojas de acanto. La cruz, lisa y de palos cuadrados, muestra la única imagen de un Cristo de buenas proporciones y detallada anatomía, crucificado con las manos cerradas y coronado de espinas bajo un pergamino de INRI.

\section{GUÍA BIBLIOGRÁFICA}

Para saber más del Santuario de San Andrés, su historia, las romerías y sus tradiciones.

«CUADERNOS DE ESTUDIOS GALLEGOS», Tomo L, Fascículo 116, Santiago 2003. 
ALONSO ROMERO, F. Santos e barcos de pedra. Vigo 1991.

BASCOY PÉREZ, R. La comarca de Ortegal en el II milenio antes de Cristo. Ortigueira 1954.

CARRÉ ALVARELLOS, L. Las leyendas tradicionales gallegas. Madrid 1977.

CHAO ESPINA, E. La costa lucense y coruñesa en los caminos de San Andrés de Teixido. La Coruña 1980.

FRAGUAS FRAGUAS, A. Romarías e Santuarios. Vigo 1988.

FRUTOS GARCÍA, P. de. Leyendas gallegas. De Breogán al fin del mundo. Madrid 1980.

GARCÍA FERNÁNDEZ-ALBALAT, B. Las rutas sagradas de Galicia. A Coruña 1999.

GONZÁLEZ REBOREDO, X.M. Lendas galegas de tradición oral. Vigo 1995.

MACIÑEIRA PARDO DE LAMA, F. San Andrés de Teixido. Historia, leyendas y tradiciones. La Coruña 1921.

MARIÑO FERRO, X.R. Las romerias/peregrinaciones y sus simbolos. Vigo 1987.

OTERO PEDRAYO, R. Pelerinaxes I (Itinerario D'Ourense a o San Andrés de Teixido). La Coruña 1929.

PENA GRAÑA, A. Narón, un concello con historia de seu. Narón 1991. PÉREZ HERVADA, E. Curanderismo y superstición en Galicia. Lugo 1984.

QUINTÁNS SUÁREZ, M. Anuario de tradicións galegas. A Coruña 1994.

«CUADERNOS DE ESTUDIOS GALLEGOS», Tomo L, Fascículo 116, Santiago 2003. 
SÁ BRAVO, H de. Creencias del costumbrismo religioso en Galicia. Pontevedra 1991.

SARMIENTO, Fray Martín. Viaje a Galicia 1754-1755. (Notas de F.J. Sánchez Cantón y J.M. Pita Andrade). Santiago 1950.

TABOADA CHIVITE, X. Ritos y creencias gallegas. A Coruña 1980.

USERO, R. El santuario de San Andrés de Teixido. Cedeira 1992.

Para conocer mejor los cruceros

RODRÍGUEZ CASTELAO, A. As cruces de pedra na Galiza. Madrid 1975.

LAREDO VERDEJO, J.M. Os nosos cruceiros, tomos I y II. A Coruña 1993.

VALLE PÈREZ, J.C. Gran Enciclopedia Gallega. Tomo VIII, Voz Cruceiros. Santiago-Gijón 1974-1987.

FERNÁNDEZ DE LA CIGOÑA NÚÑEZ, E. Cruces e cruceiros de ánimas de Galicia. Vigo 1996.

MARTÍN RUIZ, L. Cruceiros na provincia da Coruña. Tomos I al IV. A Coruña 1999.

BURGOA FERNÁNDEZ, J.J. «Los cruceros del Camino Inglés. O Camiño Inglés e as rutas atlánticas de peregrinación a Compostela». Aulas no Camiño. Universidade da Coruña. Ferrol 1997.

BURGOA FERNÁNDEZ, J.J. Cruceros y petos de los municipios de Moeche, Somozas y San Sadurniño. Comunicación presentada en el Congreso sobre Patrimonio Cultural da Diócesis de Mondoñedo-Ferrol. Ferrol 1999.

«CUADERNOS DE ESTUDIOS GALLEGOS», Tomo L, Fascículo 116, Santiago 2003. 
BURGOA FERNÁNDEZ, J.J. «Los cruceros de Neda, Narón y Valdoviño». Revista de Neda, números 2 y 3. Neda 1999 y 2000.

BURGOA FERNÁNDEZ, J.J. Cruceros y cruces de Ferrolterra. Ferrol, 2001.

BURGOA FERNÁNDEZ, J.J. «Los cruceros del municipio de Cedeira».

Cuadernos Artabros (en prensa). 